\title{
KISA SÜRELİ GÜÇ KALITESİ BOZULMALARININ DALGACIK ANALIZİ VE RASTGELE ORMAN YÖNTEMİ İLE SINIFLANDIRILMASI
}

\author{
Mustafa ERCİRE \\ Abdurrahman ÜNSAL
}

Öz: Elektrik güç sisteminde kalite kavramı giderek artan bir öneme sahiptir. Güç kalitesi bozulmaları (GKB), bir güç sisteminin akım, gerilim ve frekansında meydana gelen bozulmaları kapsar. GKB içinde, kısa süreli RMS değişimleri ile süreksiz olaylar en yüksek orana sahiptir. Bu bozulmaların doğru tespit edilmesi önemlidir. Bu çalışmada matematiksel olarak modellenen kısa süreli RMS değişimleri ve süreksiz olaylar Rastgele Orman (RO) sınıflandırıcısı ile sınıflandırılmıştır. Öznitelik vektörü Ayrık Dalgacık Dönüşümü (ADD) ile oluşturulmuştur. ADD katsayılarının enerji, kayıklık ve basıklık değerlerinden oluşturulan öznitelik vektörü RO sınıflandırıcısına uygulanmıştır. ADD’nin sınıflandırma başarımına etkisi farklı ayrışım seviyeleri ile analiz edilmiştir. Güç sistemlerinde farklı seviyelerde var olan gürültünün sınıflandırma başarımına etkisi de analiz edilmiştir. RO sınıflandırıcısının farklı ADD seviyelerinde ve farklı gürültü düzeylerinde performansı değerlendirilmiştir. Gürültü içeren bozulmalarda doğruluk, $50 \mathrm{~dB}$ gürülttü içeren olaylarda $\% 99,8$ oranında, $40 \mathrm{~dB}$ gürülttü içeren olaylarda $\% 99,4$ oranında, $30 \mathrm{~dB}$ gürültü içeren olaylarda da \%98,5 oranında elde edilmiştir. Gürültü düzeyinin $50 \mathrm{~dB}, 40 \mathrm{~dB}$ ve $30 \mathrm{~dB}$ olarak birlikte değerlendirildiği bozulmalarda doğruluk oranı \%99,6 olarak elde edilmiştir. Sonuçlar kısa vadeli RMS değişimlerinin ve süreksiz olayların RO sınıflandırıcı ile yüksek doğruluk oranıyla ile sınıflandırıldığını göstermektedir.

Anahtar Kelimeler: Güç Kalitesi, Güç Kalitesi Bozulmaları, Dalgacık Analizi, Rastgele Orman Yöntemi, Sinıflandırma

\section{Classification of Short-Term Power Quality Disturbances by Wavelet Analysis and Random Forest Method}

\begin{abstract}
The concept of quality in electrical power system has an increasing importance. Distortions in the voltage, current and frequency of a power system have adverse effects especially in economic terms. Among the power quality distortions, short-term RMS variations and transients have the highest rate. In this study, short-term RMS variations and transients which have been mathematically modeled were classified with the Random Forest (RF) classifier. The feature vector which consists of energy, skewness and kurtosis values of the DWT coefficients was applied to the RF classifier. The performance of DWT on classification performance was analyzed with different levels of decomposition. The effect of the noise on the classification performance is also analyzed. The performance of the RF classifier at different DWT levels and noise levels was evaluated. Accuracy in noise-containing disturbances was $99.8 \%$ in events with $50 \mathrm{~dB}$ noise, $99.4 \%$ in events with $40 \mathrm{~dB}$ noise, and $98.5 \%$ in events with $30 \mathrm{~dB}$ noise. The accuracy rate was obtained as $99.6 \%$ in the distortions where $50 \mathrm{~dB}, 40 \mathrm{~dB}$ and $30 \mathrm{~dB}$ noise levels were evaluated together. The results show that by using a RO classifier short-term RMS variations and transients are classified with high accuracy rate.
\end{abstract}

\footnotetext{
"Kütahya Dumlupınar Üniversitesi, Gediz Meslek Yüksekokulu, Bilgisayar Teknolojileri Bölümü, 43600, Gediz, Kütahya

** Kütahya Dumlupınar Üniversitesi, Elektrik-Elektronik Mühendisliği Bölümü, 43100, Merkez, Kütahya

İletişim Yazarı: Abdurrahman ÜNSAL (abdurrahman.unsal@dpu.edu.tr)
} 
Keywords: Power Quality, Power Quality Disturbances, Wavelet Analysis, Random Forest Method, Classification

\section{GÍRIS}

Elektrik enerjisine olan bağımlılık arttıkça iletimi ve dağıtımının yanında tüketiminin de kalite kavramını etkilemeye başladığı görülmektedir. Özellikle yarı iletken temelli aktif elektronik bileşenler içeren aygıtların kullanımının yaygınlaşması ile kullanıcı taraflı bozucu etkiler artış göstermektedir. Güç sistemi üzerinde frekans, gerilim ve akım bileşenleri için belirli standartların tanımlanmasıyla "Güç Kalitesi" (GK) kavramı ortaya çıkmıştır. Güç sistemi bileşenlerinde ortaya çıkan bozulmalar genel olarak "Güç Kalitesi Bozulması" olarak adlandırılmıştır. GKB'ler için kısaca bozulma ifadesi kullanılmıştır.

Elektrik enerjisine bağımlı hale gelen gündelik hayatta bozulmaların doğru tespit edilebilmesi iki açıdan önemlidir. Bunlar, bozulmaya yol açan etkenlerin ortadan kaldırılması ve önleyici tedbirlerin alınmasıdır. Her iki açıdan da yaklaşıldığında bozulmaların göz ardı edilemeyecek ekonomik etkilerinin azaltılması mümkün olacaktır.

Ekonomik maliyete doğrudan etkiler arasında üretimde kayıp yaşanması, kaynak ve zaman kaybı, yarı-mamul firelerinin oluşması, üretim sürecinin yeniden başlatılması, donanım hasarları, insan sağlı̆̆ 1 ve güvenliği ile ilgili sorunlar, çevresel ve finansal yaptırımlar ve diğer ek maliyetler sayılabilir. Dolaylı ekonomik maliyetler olarak üretimde yaşanan gecikmeler ve pazar pay1 kaybından kaynaklanan maliyetler bulunmaktadır (Sharma ve diğ., 2018).

Elektrik enerjisi için temel kalite beklentisi kesintisiz, anma değerlerinde ve uygulandığ aygıtlarda zarara yol açmayan bir biçimde olmasıdır. Üreticiler açısından güç kalitesi sistem güvenilirliğini ifade etmektedir. Donanım üreticileri için güç kalitesi donanımların düzgün çalışmasına elverişli seviyede enerji olmaktadır. Süreçlerin, işlemlerin ve işletmelerin süreklilik içinde çalışmalarını sağlayacak enerji, uç kullanıcılar açısından "kaliteli enerji" olarak düşünülmektedir (Ibrahim ve Morcos, 2002).

Bozulmalar IEEE 1159-2019 standardında 7 farklı ana başlıkta sınıflandırılmıştır (Tablo 1). Bunlar süreksiz olaylar (transients), kısa süreli RMS değişimleri (short duration RMS variations), uzun süreli RMS değişimleri (long duration RMS variations), dengesizlik (imbalance), dalga biçimi bozulmaları (waveform distortions), gerilim dalgalanmaları (voltage fluctations) ve güç frekansı değişimleridir (frequency variations) (IEEE Std. 1159-2019).

GKB'lerin tespiti ve sınıflandırılması için güç sistemi bileşenlerinden gerilim, akım ve frekans değerlerinin zaman içindeki değişimlerinden bazı temel bilgiler elde edilebilmektedir. Bozulma olayına ilişkin önemli diğer bazı bilgileri elde edebilmek için çeşitli dönüşüm yöntemlerinden faydalanılmaktadır.

Güç kalitesi alanında yapılan çalışmalarda, öznitelik çıkarımı amacıyla kullanılan belli başlı dönüşüm yöntemleri bulunmaktadır. Fourier Dönüşümü (FD), S-Dönüşümü (SD), Hilbert Haung Dönüşümü (HHD) ve Dalgacık Dönüşümü (DD) yaygın olarak kullanılan dönüşüm yöntemleridir (Mahela ve diğ., 2015). Bozulmaların sınıflandırılması için yapılan çalışmalarda kullanılan yöntemler arasında Destek Vektör Makinesi (DVM), Yapay Sinir Ağları (YSA), bulanık uzmansistemler, Genetik Algoritma (GA) ve diğer çeşitli sınıflandırma yöntemleri bulunmaktadır (Mahela ve diğ., 2015).

Sınıflandırma üzerine yapılan çalışmalarda karar ağaçları da yaygın olarak kullanılmaktadır. Tek bir karar ağacı yerine birden çok ağacın oluşturduğu ağaç topluluğu yaklaşımı tekil karar ağacına göre daha başarılı sonuçlar vermektedir. Topluluk öğrenmesi olarak da ifade edilen yöntemlerden biri de Rastgele Orman (RO) yöntemidir. RO yöntemi son yıllarda GK alanında yapılan çalışmalarda kullanılmaktadır. 
Tablo 1. Güç Kalitesi Bozulmaları (IEEE Std. 1159-2019)

\begin{tabular}{|c|c|c|c|}
\hline Kategori & $\begin{array}{c}\text { Tipik Spektral } \\
\text { İçerik }\end{array}$ & Tipik Süre & $\begin{array}{l}\text { Tipik } \\
\text { Gerilim } \\
\text { Genliği }\end{array}$ \\
\hline $\begin{array}{l}\text { 1. Süreksiz Olaylar } \\
\text { 1.1. Dürtüsel } \\
\text { 1.1.1. Nano Saniye } \\
\text { 1.1.2. Mikro Saniye } \\
\text { 1.1.3. Mili Saniye } \\
\text { 1.2. Salınımlı } \\
\text { 1.2.1. Düşük Frekans } \\
\text { 1.2.2. Orta Frekans } \\
\text { 1.2.3. Yüksek Frekans }\end{array}$ & $\begin{array}{c}5 \mathrm{~ns} \text { yükselme } \\
1 \mu \mathrm{s} \text { yükselme } \\
0,1 \mathrm{~ms} \text { yükselme } \\
\\
<5 \mathrm{kHz} \\
5-500 \mathrm{kHz} \\
0,5-5 \mathrm{MHz}\end{array}$ & $\begin{array}{c}<50 \mathrm{~ns} \\
50 \mathrm{~ns}-1 \mathrm{~ms} \\
>1 \mathrm{~ms} \\
0,3-50 \mathrm{~ms} \\
20 \mu \mathrm{s} \\
5 \mu \mathrm{s}\end{array}$ & $\begin{array}{l}0-4 \mathrm{pu}^{\mathrm{a}} \\
0-8 \mathrm{pu} \\
0-4 \mathrm{pu}\end{array}$ \\
\hline $\begin{array}{l}\text { 2. Kisa Süreli RMS Değişimleri } \\
\text { 2.1. Ani } \\
\text { 2.1.1. Çökme } \\
\text { 2.1.2. Şişme } \\
\text { 2.2. Anlık } \\
\text { 2.2.1. Kesinti } \\
\text { 2.2.2. Çökme } \\
\text { 2.2.3. Şişme } \\
\text { 2.3. Geçici } \\
\text { 2.2.1. Kesinti } \\
\text { 2.2.2. Çökme } \\
\text { 2.2.3. Şişme }\end{array}$ & & $\begin{array}{l}0,5-30 \text { Periyot } \\
0,5-30 \text { Periyot } \\
0,5-30 \text { Periyot } \\
0,5 \text { Periyot }-3 \mathrm{~s} \\
0,5 \text { Periyot }-3 \mathrm{~s} \\
>3 \mathrm{~s}-1 \mathrm{dk} \\
>3 \mathrm{~s}-1 \mathrm{dk} \\
>3 \mathrm{~s}-1 \mathrm{dk}\end{array}$ & $\begin{array}{l}0,1-0,9 \mathrm{pu} \\
1,1-1,8 \mathrm{pu} \\
<0,1 \mathrm{pu} \\
0,1-0,9 \mathrm{pu} \\
1,1-1,4 \mathrm{pu} \\
<0,1 \mathrm{pu} \\
0,1-0,9 \mathrm{pu} \\
1,1-1,2 \mathrm{pu}\end{array}$ \\
\hline $\begin{array}{l}\text { 3. Uzun Süreli RMS Değişimleri } \\
\text { 3.1. Kesinti, Sürekli } \\
\text { 3.2. Düşük Gerilim } \\
\text { 3.3. Aşırı Gerilim } \\
\text { 3.4. Akım Yük Aşımı }\end{array}$ & & $\begin{array}{l}>1 \mathrm{dk} \\
>1 \mathrm{dk} \\
>1 \mathrm{dk} \\
>1 \mathrm{dk}\end{array}$ & $\begin{array}{l}0,0 \mathrm{pu} \\
0,8-0,9 \mathrm{pu} \\
1,1-1,2 \mathrm{pu}\end{array}$ \\
\hline $\begin{array}{l}\text { 4. Dengesizlik } \\
\text { 4.1. Gerilim } \\
\text { 4.2. Akım }\end{array}$ & & $\begin{array}{l}\text { Kararl1 Durum } \\
\text { Kararl1 Durum }\end{array}$ & $\begin{array}{c}0,5-2,0 \% \\
1,0-30 \%\end{array}$ \\
\hline $\begin{array}{l}\text { 5. Dalga Biçimi Bozulması } \\
\text { 5.1. DC Ofset } \\
\text { 5.2. Harmonikler } \\
\text { 5.3. Ara Harmonikler } \\
\text { 5.4. Çentik } \\
\text { 5.5. Gürültü }\end{array}$ & $\begin{array}{l}0-9 \mathrm{kHz} \\
0-9 \mathrm{kHz} \\
\text { Genişbant }\end{array}$ & $\begin{array}{l}\text { Kararlı Durum } \\
\text { Kararlı Durum } \\
\text { Kararlı Durum } \\
\text { Kararlı Durum } \\
\text { Kararlı Durum }\end{array}$ & $\begin{array}{l}0-0,1 \% \\
0-20 \% \\
0-2 \% \\
0-1 \%\end{array}$ \\
\hline 6. Gerilim Dalgalanmaları & $<25 \mathrm{~Hz}$ & Aralıklı & $\begin{array}{c}0,1-7 \% \\
0,2-2 \mathrm{P}_{\mathrm{st}}^{\mathrm{b}}\end{array}$ \\
\hline 7. Güç Frekansı Değişimleri & & $<10 \mathrm{~s}$ & $\pm 0,1 \mathrm{~Hz}$ \\
\hline \multicolumn{4}{|c|}{$\begin{array}{l}\text { a pu niceliği birim başına anlamında olup boyutsuzdur. } 1,0 \text { pu niceliği \%100'e karş1lık } \\
\text { gelmektedir. Genellikle normal şart } 1,0 \text { pu olarak kabul edilir. Tabloda süreksiz olaylar için } \\
\text { referans olarak normal tepe değeri alınırken RMS değişimleri için ise referans olarak RMS } \\
\text { değeri alınmıştır. }\end{array}$} \\
\hline
\end{tabular}

Upadhyaya ve diğ. (2015) bozulmaların hızlı algılanması ve karakterize edilmesi için hibrit bir yöntem önermiştir. Bozulma içeren olay işaretlerinden öznitelik elde edilmek üzere DD temelinde geliştirilmiş maksimum örtüşen ayrık dalgacık dönüşümü (MODWT-maximum overlapping discrete wavelet transform) ve ikinci-nesil dalgacık dönüşümü (SGWT-secondgeneration wavelet transform) yöntemlerini kullanılmıştır. Bozulmalar ilgili yöntemlerle elde edilen enerji, standart sapma ve entropi öznitelikleri üzerinden RO yöntemi ile kategorize edilmiştir. 
Huang ve diğ. (2016) bozulmalardan öznitelik seçimi ve GKB sınıflandırması için, entropiönem (EnI-Entropy-Importance) tabanlı RO modeli önermiştir. Özniteliklerin elde edilmesinde, S-Dönüşümü (ST-S-Transform) kullanılmıştır. Çok sayıda öznitelik elde edilerek, bunların içinden önem derecesi yüksek olanlar tespit edilmeye çalışılmıştır. Özellik seçiminin, RO sınıflandırıcısı başarımına etkileri analiz edilmiştir.

Reddy ve Sodhi (2017) tekil ve çoklu bozulmaların doğru tespiti ve sınıflandırmasına yönelik çalışmıştır. Bu amaçla modifiye edilmiş en uygun hızlı ayrık S-Dönüşümü (MOFDST-modified optimal fast discrete ST) yöntemi kullanılmıştır. Bu yöntem ile elde edilen faz ve genlik konturlarının enerji, standart sapma, basıklık, kayıklık gibi öznitelikleri RO sınıflandırıcısına uygulanmıştır. Önerilen sistem gerçek saha verileri ile test edildiğinde, oldukça umut verici sonuçların elde edildiği belirtilmiştir.

Borges ve diğ. (2015) bozulmaların sinıflandırılmasında, karar ağacı yöntemlerinden J48 algoritması ile RO yönteminin performanslarını karşılaştırmışlardır. Büyük miktarda veriler üzerinde yapılan çalışmalarda daha olumlu sonuçların elde edildiğini belirttikleri RO yönteminin, tekil karar ağacı algoritmalarına oranla bozulmalarda daha yüksek performans gösterdiğini ortaya koymuşlardır.

Jamali ve diğ. (2018) bozulmaların minimum hesaplama karmaşıklığı ile doğru sınıflandırılabilmesi üzerinde çalışmışlardır. Öznitelikler belirlenirken sıklıkla başvurulan istatistiksel değerlerden enerji, entropi, standart sapma, basıklık, kayıklık, RMS ve ortalama değerlerinden faydalanmışlardır. Özniteliklerin elde edilmesinde benzer çalışmalarda sıkça karşılaşılan birçok dönüşüm yöntemi bir arada kullanılmıştır. Ortaya çıkan tüm öznitelikler içinden en efektif sonucu elde edebilmek için öznitelik seçimi yapılmıştır. Seçilen öznitelikler ile farklı sınıflandırma algoritmalarının sonuçları değerlendirilmiştir. Değerlendirme sonucunda en başarılı sonuçların RO sınıflandırıcısı ile elde edildiği vurgulanmıştır.

Markovska ve Taskovski (2017a) bozulmaların sinıflandırılmasında kullanılan dalgacık temelli özniteliklerin etkinliği ve seçimi üzerinde çalışmışlardır. Özniteliklerin farklı seçilmiş kombinasyonlarının sınıflandırma doğruluğuna etkisini 7 ve 11 sınıflı bozulma setleri ile ayrı ayrı incelemişlerdir. İncelenen öznitelikleri temel istatistiksel değerlerden oluşturmuşlardır. Sınıflandırıcılar arası verimlilik farkını araştırmak üzere DVM, karar ağacı ve RO yöntemleri karşılaş̧tırılmıştır. RO yöntemi ile elde edilen sonuçlarda, sınıf sayısı 11 olan veri setinde diğer yöntemlere oranla daha başarılı sonuçlar elde edildiği gözlenmiştir.

Markovska ve Taskovski (2017b) bozulmaları sınıflandırmak için dalgacık tabanlı ve en uygun özniteliklerin seçimine dayanan bir RO sinıflandırıcısı önermişlerdir. Bozulma olayı işaretlerine Ayrık DD uygulanarak oluşturulan katsayılardan elde edilen enerji ve log-enerji entropi değerlerinin öznitelikleri oluşturulmuştur. Daha önce yapılan çalışmalarla karşılaştırıldığında RO sınıflandırıcısının düşük hata oranıyla sınıflandırma yaptığı belirtilmiştir.

Kiranmai ve Laxmi (2018) gerilimde meydana gelen çökme, şişme, kesinti ve dengesizlik bozulmalarını, veri madenciliği yaklaşımıyla sınıflandırma üzerine çalışmışlardır. Sınıflandırıcı olarak J48 karar ağacı, rastgele ağaç ve RO yöntemleri kullanılmıştır. Olay işaretlerinin doğrudan sınıflandırılması ve olay işaretlerinden elde edilen en büyük, en küçük ve ortalama gerilim değerlerinin de eklendiği iki farklı veri seti ile yapılan çalışmada RO sınıflandırıcısının başarımı vurgulanmıştır.

$\mathrm{Bu}$ çalışmada, süreksiz olaylar ve kısa süreli RMS değişimi olaylarının sınıflandırılması amaçlanmıştır. Sınıflandırma kapsamına alınan bozulmaların ortak özelliği gerilim üzerinde meydana gelmeleri, tekrarlı ve kalıcı olmamaları, kısa ve belirli bir sürede başlayıp sonlanıyor olmaları, ve toplam bozulmalar içindeki oranının, Şekil 1'de verildiği gibi \%70'in üzerinde olmasidır (Sharma ve diğ., 2018).

Bozulmalar LabVIEW yazılımı kullanılarak matematiksel modele dayalı olarak oluşturulmuştur. LabVIEW, uygulama geliştirmek için metin tabanlı kod yazımı yerine simgelerin kullanıldığı grafik tabanlı programlama dilidir. (http://www.ni.com/pdf/manuals/373427f.pdf). 


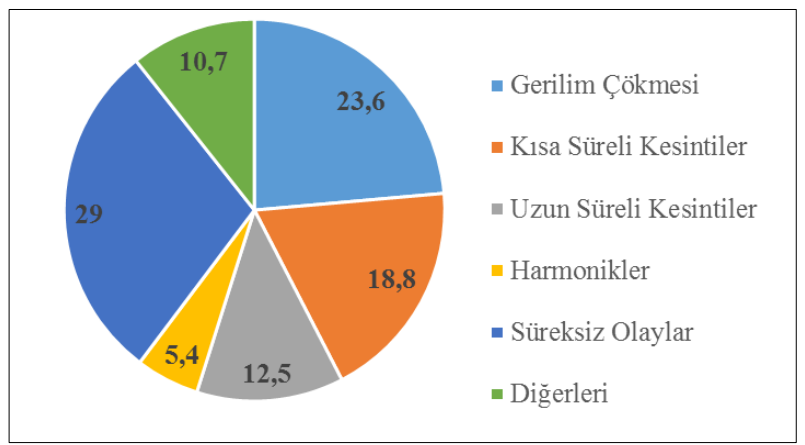

Şekil 1:

GKB 'lerin gerçekleşme oranları (Sharma ve diğ., 2018)

Çalışmada, durağan olmayan ve azami 10 periyotluk sürede sona eren kısa süreli RMS değişimleri ve genellikle 1 periyotluk süre içinde sona eren süreksiz olayların asgari öznitelik ile sınıflandırılması üzerinde çalışılmıştır. Bozulma olaylarından öznitelik çıkarımı için Ayrık Dalgacık Dönüşümü (ADD) yöntemi kullanılmıştır. ADD detay ve yaklaşım katsayılarından elde edilen enerji, basıklık ve kayıklık değerleri ile oluşturulan öznitelik vektörü, RO sınıflandırıcısına uygulanarak sınıflandırma yapılmıştır. ADD seviyesinin sınıflandırma başarımına etkisi farklı seviyeler ile çalışılarak analiz edilmiştir. Bozulma olaylarının gürültülü seçenekleri de hazırlanarak gürültünün başarıma etkisi irdelenmiştir.

Tablo 2'de DD temelli öznitelik çıkarımı yapılarak RO yöntemi ile sınıflandırma uygulanmış benzer çalışmalar ve bu çalışmaların sonuçları verilmiştir. Tüm çalışmalarda simülasyon verileri kullanılmıştır. Çalışmalar incelendiğinde örneğin harmonikli gerilim çökmesi gibi birden fazla bozulmanın birlikte değerlendirilerek sınıfların oluşturulduğu, harmonik ve çentik gibi belirli bir sürede tekrarlı ve sürekli olarak gerçekleşen olayların kısa süreli ve geçici olaylarla birlikte değerlendirildiği, süreksiz olayların tek sınıf altında kabul edildiği görülmüştür.

Tablo 2. Literatürdeki DD ve RO temelli çalışmaların sonuçları

\begin{tabular}{|c|c|c|c|c|c|}
\hline Kaynak & $\begin{array}{c}\text { Öznitelik Çıkarım } \\
\text { Tekniği }\end{array}$ & $\begin{array}{l}\text { Öznitelik } \\
\text { Sayısı }\end{array}$ & $\begin{array}{l}\text { Olay Sınıfı } \\
\text { Sayısı }\end{array}$ & $\begin{array}{l}\text { Gürülttü } \\
\text { (dB) }\end{array}$ & $\underset{\%}{\text { Doğruluk }}$ \\
\hline \multirow{6}{*}{ (Upadhyaya ve diğ., 2015) } & \multirow{3}{*}{ MODWT } & \multirow{6}{*}{4} & \multirow{6}{*}{10} & Yok & 99,92 \\
\hline & & & & 40 & 99,94 \\
\hline & & & & 30 & 99,90 \\
\hline & \multirow{3}{*}{ SGWT } & & & Yok & 99,96 \\
\hline & & & & 40 & 99,95 \\
\hline & & & & 30 & 99,91 \\
\hline \multirow{3}{*}{ (Huang ve diğ., 2016) } & \multirow{3}{*}{ DWT } & \multirow{3}{*}{23} & \multirow{3}{*}{14} & 50 & 98,40 \\
\hline & & & & 40 & 98,80 \\
\hline & & & & 30 & 97,10 \\
\hline (Jamali ve diğ., 2018) & WT & 13 & 16 & 60 & 99,37 \\
\hline \multirow{10}{*}{ (Markovska ve Taskovski, 2017a) } & \multirow{10}{*}{ DWT } & \multirow{2}{*}{7} & 7 & \multirow{10}{*}{ Yok } & 96,39 \\
\hline & & & 11 & & 95,99 \\
\hline & & \multirow{2}{*}{14} & 7 & & 99,49 \\
\hline & & & 11 & & 98,27 \\
\hline & & \multirow{2}{*}{21} & 7 & & 98,54 \\
\hline & & & 11 & & 97,65 \\
\hline & & \multirow{2}{*}{28} & 7 & & 99,41 \\
\hline & & & 11 & & 98,32 \\
\hline & & \multirow{2}{*}{63} & 7 & & 99,30 \\
\hline & & & 11 & & 98,37 \\
\hline
\end{tabular}


Ercire M., Ünsal A.: Kısa Süre. Güç Kalite. Bozulma. Dalgack. Analiz. Ve Rast. Orman Yönt. İle Sınıf.

Bu çalışmanın katkısı daha az öznitelik kullanılarak sınıflandırma yapmasıdır. Olay sınıflarının seçiminde 1 saniyeden daha kısa sürede sonlanan ancak güç sistemine olumsuz etkisi fazla olan bozulmalara odaklanılarak, en az öznitelik ile yüksek doğrulukta sınıflandırma üzerinde durulmuştur.

\section{MATERYEL VE YÖNTEM}

\subsection{Güç Kalitesi Bozulması Olay İşaretleri}

Çalışma kapsamında şebeke geriliminde meydana gelen süreksiz olaylar ve kısa süreli RMS değişimleri incelenmektedir. Süreksiz olaylar dürtüsel ve salınımlı olmak üzere iki alt sınıfa ayrılmaktadır. Kısa süreli RMS değişimleri ise gerilim çökmesi, gerilim şişmesi ve gerilim kesintisi olmak üzere üç alt sınıfa ayrılmaktadır. Bozulma içermeyen normal durumla birlikte toplam 6 farklı sınıf oluşmaktadır. Tablo 3'de verilen matematiksel denklemler ile üretilen olay işaretleri Tan ve Ramachandaramurthy (2010) tarafindan önerilen modelden uyarlanarak 12,8 $\mathrm{kHz}$ örnekleme frekansında elde edilmiştir.

Tablo 3. Bozulma olay işaretleri eşitlikleri

\begin{tabular}{|c|c|c|}
\hline Sinıf & Denklem & Parametreler \\
\hline $\begin{array}{l}\text { Normal } \\
\quad(\text { S1) }\end{array}$ & $V(t)=A * \sin (\omega t)$ & $\begin{array}{c}A=\sqrt{2}(1 p u R M S) \\
\omega=2 \pi f \\
f=50 \mathrm{~Hz}\end{array}$ \\
\hline $\begin{array}{c}\text { Gerilim } \\
\text { Çökmesi } \\
\text { (S2) } \\
\end{array}$ & $V(t)=A *\left(1-\alpha\left(u\left(t-t_{1}\right)-u\left(t-t_{2}\right)\right)\right) * \sin (\omega t)$ & $\begin{array}{c}T<t_{1}<10,5 T \\
T / 2 \leq\left(t_{2}-t_{1}\right) \leq 10 T \\
0,12 \leq \alpha<0,88\end{array}$ \\
\hline $\begin{array}{c}\text { Gerilim } \\
\text { Şişmesi } \\
\text { (S3) } \\
\end{array}$ & $V(t)=A *\left(1+\alpha\left(u\left(t-t_{1}\right)-u\left(t-t_{2}\right)\right)\right) * \sin (\omega t)$ & $\begin{array}{c}T<t_{1}<10,5 T \\
T / 2 \leq\left(t_{2}-t_{1}\right) \leq 10 T \\
0,12 \leq \alpha<0,8\end{array}$ \\
\hline $\begin{array}{l}\text { Gerilim } \\
\text { Kesintisi } \\
\quad \text { (S4) }\end{array}$ & $V(t)=A *\left(1-\alpha\left(u\left(t-t_{1}\right)-u\left(t-t_{2}\right)\right)\right) * \sin (\omega t)$ & $\begin{array}{c}T<t_{1}<10,5 T \\
T / 2 \leq\left(t_{2}-t_{1}\right) \leq 10 T \\
0,92 \leq \alpha<1,0\end{array}$ \\
\hline $\begin{array}{l}\text { Dürtüsel } \\
\quad \text { (S5) }\end{array}$ & $V(t)=A * \sin (\omega t)+\alpha\left(u\left(t-t_{1}\right) *\left(e^{-\left(\left(t-t_{1}\right) * \rho\right)}\right)\right)$ & $\begin{array}{c}T<t_{1}<10,5 T \\
0,3 \leq \alpha<1,0 \\
1000<\rho<3600\end{array}$ \\
\hline $\begin{array}{l}\text { Salınımlı } \\
\quad \text { (S6) }\end{array}$ & $V(t)=A * \sin (\omega t)+\alpha\left(u\left(t-t_{1}\right) * \sin \left(\omega_{o} t\right) *\left(e^{-\left(\left(t-t_{1}\right) * \rho\right)}\right)\right)$ & $\begin{array}{c}T<t_{1}<9 T \\
0,3 \leq \alpha<1,0 \\
250<\rho<2250 \\
\omega_{o}=2 \pi f_{o} \\
500<f_{o}<4500\end{array}$ \\
\hline
\end{tabular}

\subsection{Dalgacık Analizi}

Dalgacık fikrinin temelini 1909 yılında matematikçi Alfred Haar tarafindan önerilen "Haar Dalgacığı" oluşturmaktadır. Dalgacık Dönüşümü (DD) (Wavelet Transform - WT) 1981 yılında jeofizikçi Jean Morlet tarafından önerilmiştir. 1988 yılında Stephane Mallat ve Yves Meyer tarafından çoklu çözünürlük (multiresolution) kavramı önerilmiştir. 1989 yılından itibaren dalgacık dönüşümü, işaret işleme alanında yaygın olarak kullanılmaya başlanmıştır (Chun-Lin, 2010).

DD’nin üzerine inşa edildiği dalgacık kavramı sonlu uzunlukta bir işarettir ve $\psi$ ile gösterilir. Bir işaretin dalgacık olarak kabul edilmesi ve dalgacık analizinde kullanılabilmesi için aşağıdaki iki şartı sağlaması gerekir (Misiti ve diğ., 2010). Bunlar; 
i. $\psi$ 'nin integrali sifirdır:

$$
\int_{-\infty}^{+\infty} \psi(x) d x=0
$$

ii. $\psi$ 'nin karesinin integrali bire eşittir:

$$
\int_{-\infty}^{+\infty} \psi^{2}(x) d x=1
$$

Dalgacıkların sağladığı en büyük avantajlardan biri yerel analiz yapma yeteneğidir. Daha açık bir ifadeyle, uzun bir işaretin belirli kısa bir bölgesini analiz etme avantajı sağlarlar. (Misiti ve diğ., 2010) Dalgacık analizi, bir işaretin temel dalgacığın kaydırılmış ve ölçeklendirilmiş biçimleri ile parçalanmasıdır. DD, Sürekli DD (SDD) (Continuous WT) ve Ayrık DD (ADD) (Discrete WT) olmak üzere ikiye ayrılır.

SDD, giriş işaretinin $\psi$ ile gösterilen dalgacık fonksiyonunun, ölçeklendirilmiş ve ötelenmiş biçimleriyle çarpılıp tüm zaman boyunca toplanmasından elde edilir. Bu işlemin matematiksel ifadesi eşitlik (3)'de verilmiştir.

$$
W(a, b)=\frac{1}{\sqrt{a}} \int_{-\infty}^{+\infty} f(t) \psi\left(\frac{t-b}{a}\right) d t
$$

Eşitlik (3)'de $a$ ölçeği, $b$ ötelemeyi, $f(t)$ işareti, $\psi$ ana dalgacı $\breve{g}, W(a, b)$ işaretin dalgacık dönüşümünü gösterir. Bir dalgacığın ölçeklenmesi, dalgacık işaretinin biçimsel olarak genişletilmesi veya daraltılmasını ifade etmektedir. Bir dalgacığın kaydırılması ise dalgacık işaretinin zaman ekseninde belirli bir $k$ öteleme katsayısı kadar ileri veya geri yönde yer değiştirilmesini ifade etmektedir. Bu yer değiştirme pozisyon olarak ifade edilir. Bir $f(t)$ işaretinin $k$ kadar kaydırılmış hali $f(t-k)$ biçiminde gösterilir.

SDD yöntemi, teorik olarak olası tüm ölçekler için uygulanmak istendiğinde yoğun hesaplama süreci gerektirir. Aynı zamanda büyük miktarda veri ortaya çıkarır. Genellikle ölçek ve öteleme değerleri 2'nin kuvveti olacak şekilde seçilir. SDD yönteminin bu şekilde uygulanması ADD olarak adlandırılır. Ölçekleme ve öteleme işlemleri ile gerçekleştirilen ADD sürecinin işleyişi Şekil 2'de verilmiştir. ADD yönteminin matematiksel ifadesi eşitlik (4)'de verilmiştir (Goswami ve Chan, 1999; Debnath, 2002; Vatansever, 2020;).

$$
a=\frac{1}{2^{j}}, b=\frac{1}{2^{j}} ; \quad W(a, b)=\sqrt{2^{j}} \int_{-\infty}^{+\infty} f(t) \psi\left(\frac{t-k / 2^{j}}{1 / 2^{j}}\right) d t
$$

\subsection{Rastgele Orman Yöntemi}

$\mathrm{Bu}$ yöntemin temelinde karar ağacı (decision tree) yapısı kullanılmaktadır. Orman birden fazla karar ağacı ile oluşturulmuş bir topluluktur. RO yönteminde amaç, ağaçlardan oluşan bir topluluğun eğitilmesidir. Diğer bir ifadeyle RO bir öğrenicidir. RO yöntemi, Breiman (1996) tarafından önerilen Torbalama (bagging - bootstrap aggregating) yöntemi ile Ho (1998) tarafından önerilen Rastgele Alt-Uzay (Random Sub-Space) yöntemini birleştirmiştir (Akman, 
2010). Breiman (2001), torbalama yöntemine ek bir rastgelelik katmanı ekleyerek RO yöntemini önermiştir.

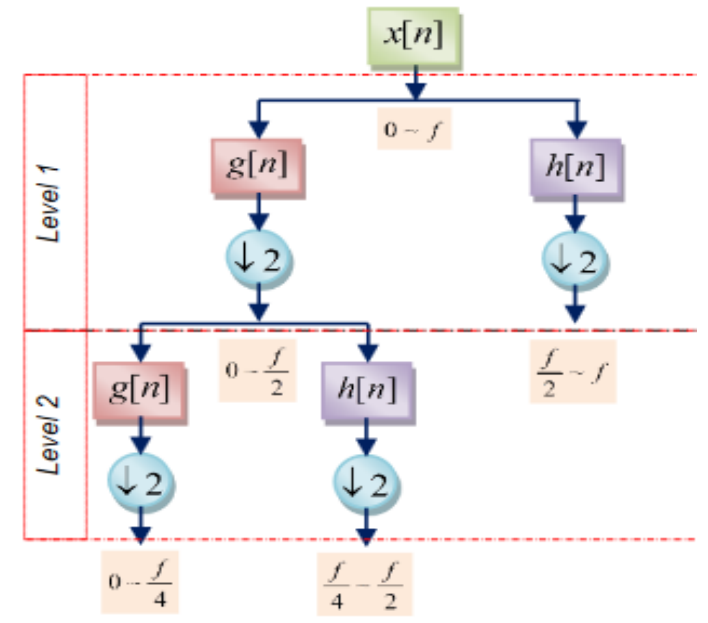

Sekil 2:

Ayrık Dalgacık Dönüşümü (Vatansever, 2020)

RO yönteminde elde bulunan veri seti bir matris gibi düşünülebilir. Matrisin her bir satırı veri setinde yer alan tekil bir vakayı tutmaktadır. Matrisin satır sayısı veri setindeki vakaların sayısına bağlıdır. Matrisin sütunları ise girdi değişkenlerini ve bunlarla ilişkilendirilmiş sınıf kararını tutmaktadır. Girdi değişkenleri sınıf kararının oluşmasında etkisi olan ya da etkisi olduğuna inanılan verilerden oluşur. Bu veriler sayısal, çoktan seçmeli, evet/hayır vb. gibi farklı veri türlerinden oluşabilir.

RO yöntemi iki farklı veri grubuna ihtiyaç duyar. Bunlar eğitim veri seti (in-bag) ve test veri setidir (out-of-bag). Eğitim veri seti verilerin 2/3'ü, test veri seti ise 1/3'ü oranındadır. Eğitim veri seti ağacın yetiştirilmesi (training) için kullanılır. Test veri seti ise ağacın genelleştirilmiş hata oranını (oob error) belirlemek için kullanılır. Ormanda yer alan her ağaç için orijinal veri setinden alınmak üzere farklı veri seti kullanılır. Her ağacın eğitim ve test veri setleri farklıdır. Orijinal veri setinde test amaçlı ayrılmış veri grubu var ise bu veri grubu ormanın genel hatasını tespit etmek için kullanılır. Ağaçların tek tek hata oranlarının ortalaması ile ormanın genel hata oranı hemen hemen aynıdır. RO yönteminin işleyiş süreci Şekil 3'de verilmiştir.

Ormandaki ağaçların yetiştirilmesi sürecinde her bir ağaç diğerlerinden etkilenmeden tek başına yetiştirilir. Ağacın yetiştirilmesi klasik karar ağaçlarında kullanılan esaslara dayanır. Ağaçlar CART (Classification And Regression Tree) yöntemleri ile oluşturulurken dügümlerdeki en iyi bölünmeyi sağlamak için GINI indeksi kullanılır.

RO yönteminde her bir ağaç, verilerin farklı bir önyükleme (bootstrap) örneği kullanılarak oluşturulur. Sınıflandırma veya regresyon ağaçlarında her düğüm tüm girdi değişkenleri arasından en iyi bölünmeyi sağlayan girdi değişkeni kullanılarak belirlenirken RO yönteminde ise Rastgele Alt-Uzay yöntemine dayanılarak, o düğüm için rastgele seçilen değişkenler arasından en iyi bölünmeyi sağlayan değişkenin belirlenmesiyle bölünür (Liaw ve Wiener, 2002).

En iyi bölünmeyi sağlayacak girdi değişkeninin seçiminde kullanılan rastgelelik esası ormandaki tüm ağaçları hemen hemen benzersiz kılmaktadır. Rastgele seçilecek girdi değişkeni sayısı (m) ile ifade edilir. Rastgele seçilecek girdi değişkeni sayısı (m) genellikle toplam girdi değişkeni sayısının karekökü alınarak belirlenir ve ağaçtaki her dü̆̆̈̈m ve ormandaki tüm ağaçlar için sabit tutulur.

Ormanda yer alan her bir ağaç kendi sınıf kararını üretir. Her bir ağacın kararı bir oy olarak değerlendirilir. En çok oyu alan sınıf ağaç topluluğunun kararı olarak kabul edilir. Bu sürecin sonucu olarak sınıflandırma doğruluğu belirgin biçimde iyileşir (Breiman, 2001). 
Ormanı oluşturan her bir ağaç aşağıdaki algoritma kullanılarak oluşturulur (Breiman, 2001):

i. $\quad$ Ağacı yetiştirmek için kullanılacak veri setinde $N$ farkl vaka olsun. Bu veri seti içinden rastgele ve yer değiştirmeli olacak şekilde, $N$ adet vaka önyükleme (bootstrap) yoluyla örnek olarak alınır. Bu örnek ăgacı yetiştirmek için kullanilacak eğitim veri setini oluşturacaktır.

ii. $\quad M$ girdi değişkenlerinin sayısıdır. Ăgacın her düğümü için $M$ değerinden çok daha küçük olmak üzere $(m<<M)$ tanımlanmış sabit bir $m$ değeri vardır. $m$ değeri ăgaçtaki her dügü̈m için en iyi bölünmenin bulunması amacıyla kullanılacak girdi değiş̧keni sayısıdır. $m$ değerinin gösterdiği sayıda girdi değişkeni daha önce kullanılmamış girdi değişkenleri içinden rastgele seçilerek ilgili dügü̈m için en iyi bölünme sağlanır. $m$ değeri ormandaki tüm ağaçlar iç̧in sabit tutulur.

iii. Ormanda yer alan her ağaç mümkün olan en gelişmiş haliyle yetiştirilir. Budama yapılmaz.

Ormanın hata oranını iki olgu belirler. Bunlardan birincisi, iki ağaç arasındaki korelasyondur. Korelasyonun artması orman hata oranını arttırır. İkincisi ormandaki her bir ağacın sınıflandırma gücüdür. Ağacın gücü doğru sınıflandırma yapma oranıdır. Hatalı sınıflandırma oranı düşük olan bir ağaç güçlü bir sınıflandırma sağlar. Ağaçların her birinin gücünün arttırılması ağaç topluluğunun genel hata oranını düşürür. Ağacın düğümlerindeki bölünmeyi belirleyen girdi değişkenleri sayısının (m) azaltılması korelasyonu ve gücü azaltırken artırılması ise her ikisini de artırır. Korelasyonun düşük, ağacın gücünün yüksek olmasını sağlayacak en uygun $(\mathrm{m})$ değeri için bu aralık oldukça geniştir. Ağaçların eğitim sürecinde kullanılmayıp test için ayrılan veri setinin (out-of-bag) hata değeri kullanılarak bu aralıkta uygun bir (m) değeri hızlıca bulunabilir. Breiman 2001, (m) değerinin rastgele ormanların ayarlanabilen tek parametresi olduğunu belirtmiştir.

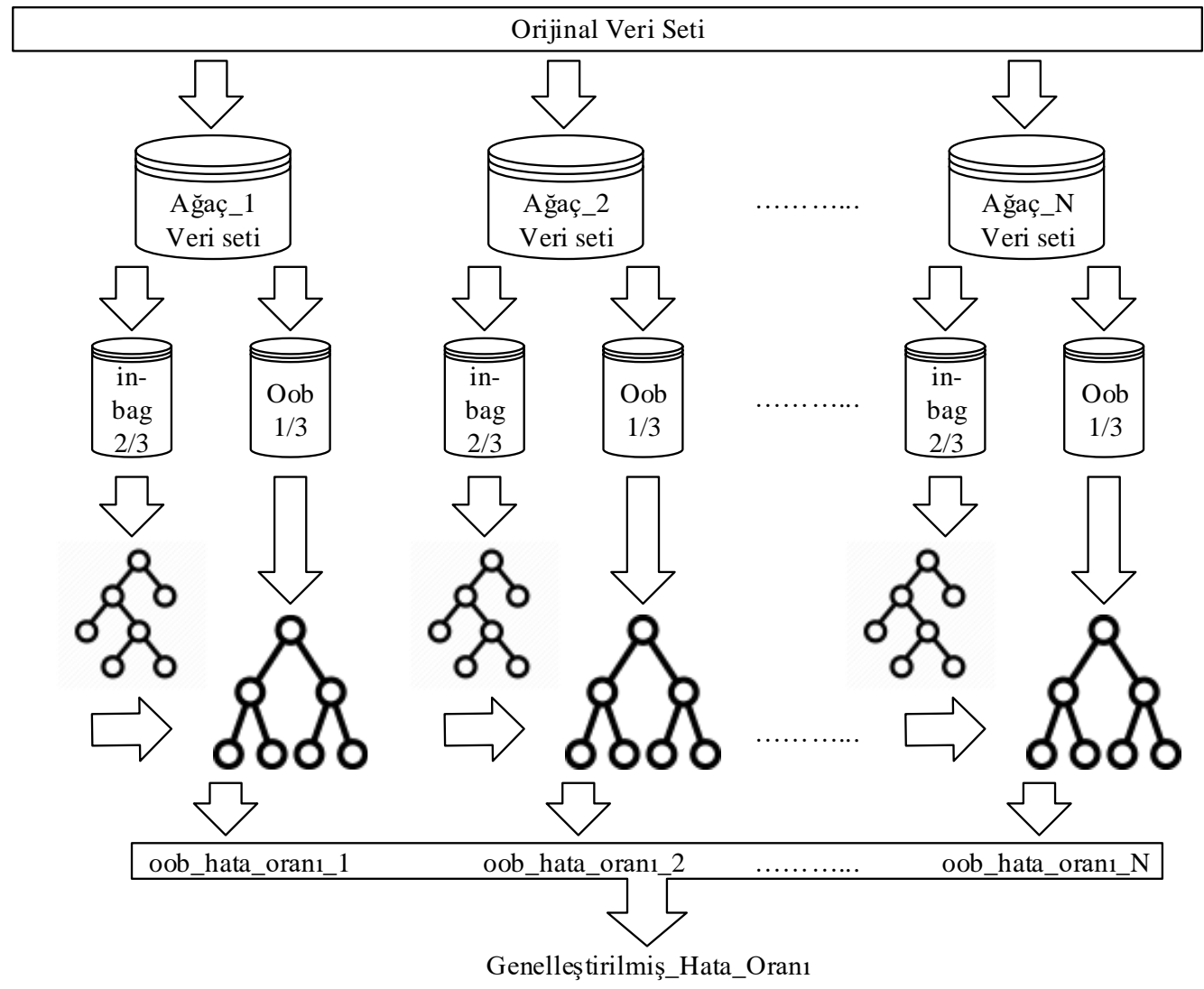

Şekil 3:

$R O$ Yöntemi $O O B$ işleyiş süreci 
Ercire M., Ünsal A.: Kısa Süre. Güç Kalite. Bozulma. Dalgack. Analiz. Ve Rast. Orman Yönt. İle Sınıf.

\section{BULGULAR VE TARTIȘMA}

Matematiksel denklemlerle modellenerek oluşturulan olay işaretleri LabVIEW yazılımı ile grafiksel programlama ortamında üretilmiştir. Güç sistemlerinde belirli seviyede gürültü bulunmaktadır. Bir güç sistemindeki kabul edilebilir gürültü, nominal genlik değerinin yaklaşık $\% 0,7$ ila $\% 0,9$ oranında genlikte ve $50 \mathrm{~dB}$ ila $48 \mathrm{~dB}$ arasındadır (Tan ve Ramachandaramurthy, 2010). Genellikle güç sistemindeki gürültü olarak normal dağılımlı ve sabit spektrumlu Gauss Beyaz Gürültüsü (GBN) (Gaussian White Noise) kabul edilir (Li ve diğ., 2021). GBN istatistiksel olarak ortalaması 0'a ve varyansı 1'e eşit olan Gauss normal dağılımına sahiptir. Bozulmaların tespitinde gürültünün başarıma olan etkisinin de incelenebilmesi için olay işaretlerine GBN eklenmiştir. Bunun için her bir olay işareti gürültüsüz olarak oluşturulup üzerine $50 \mathrm{~dB}$ düşük seviye, $40 \mathrm{~dB}$ orta seviye ve $30 \mathrm{~dB}$ yüksek seviye gürültü eklenerek ayrı ayrı kaydedilmiştir. Üretilen olay işaretlerinin örnekleri Şekil 4'de gösterilmiştir.

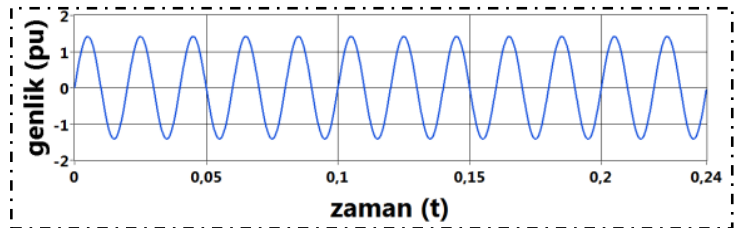

a.

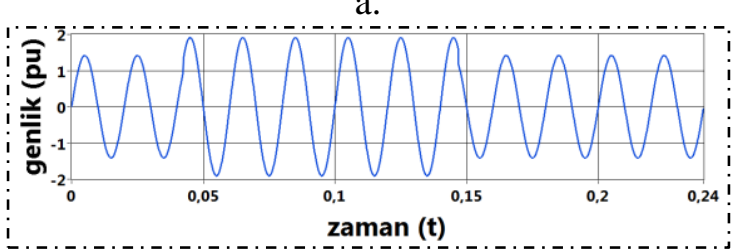

c.

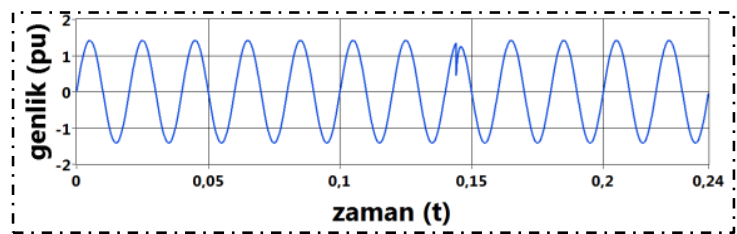

e.

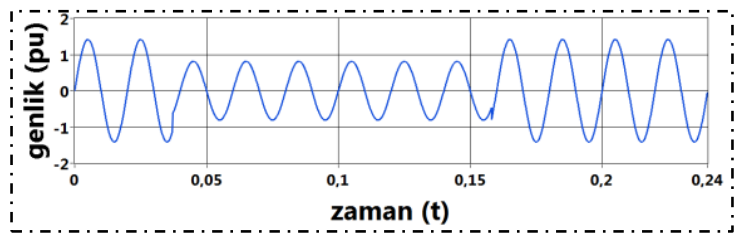

b.

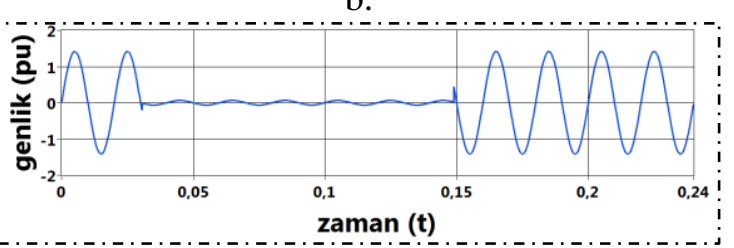

d.

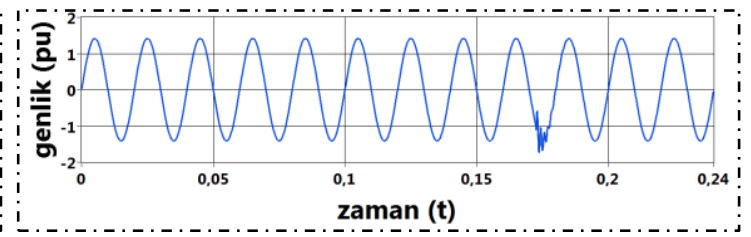

f.

Şekil 4:

Bozulma olay işaretleri;
a. Normal Durum b. Gerilim Çökmesi
c. Gerilim Şişmesi
d. Gerilim Kesintisi
e. Dürtüsel Süreksiz Olay
f. Salınımlı Süreksiz Olay

\subsection{Güç Kalitesi Bozulması Olaylarında Öznitelik Vektörü Çıkarımı}

$\mathrm{Bu}$ çalışmada, bozulmalardan öznitelik vektörü elde etmek için ADD yöntemi kullanılmıştır. İncelenen olay işaretlerinde frekans ve genlik değerlerinin olağanın dışında değişim gösterdiği noktalar bozulmaların göstergesi niteliğindedir. ADD yönteminin temel özelliği, bir işaretin durağan olmayan noktalarına karşı duyarlı olmasıdır. Bu iki husus birlikte değerlendirildiğinde ADD yönteminin uygun bir seçim olacağı öngörülmüştür. ADD yönteminin işleyişinde sadece iki parametre kullanılmaktadır. Bu parametreler ADD'nin kaç seviyeli yapılacağı ve uygulanan ana dalgacık türüdür. ADD 5-9 arasında beş farklı seviyede uygulanmıştır. Seviye sayısı arttıkça daha düşük frekans bant aralıklarında meydana gelen değişimlere karşı duyarlılık artmaktadır. Buradan hareketle ADD seviyesinin özniteliklere ve dolayısıyla sınıflandırma başarımına etkisi incelenmiştir.

Bozulmaların tespiti ve sınıflandırılması için en uygun dalgacık türü olarak kısaca db4 olarak adlandırılan "Daubechies-4" dalgacığı gösterilmiştir (Brito ve diğ., 1998). Ana dalgacık türü olarak db4 dalgacığı kullanılmıştır. ADD uygulanan olay işaretinden elde edilen detay ve 
yaklaşım katsayıları olay türlerine göre farklılık göstermektedir. Belirli seviyelerdeki katsayıların oluşturduğu işaret olayın başlangıcına, bitişine ve olay süresince gerçekleşenlere ilişkin bilgileri açığa çıkarmaktadır.

Meydana gelen farklı bozulmaların katsayılar üzerinde oluşturduğu değişimden anlamlı bir sonuç elde edebilmek için katsayılardan öznitelikler elde edilmiştir. Bu öznitelikler ortalama enerji, kayıklık (skewness) ve basıklık (kurtosis) değerlerinden oluşturulmuştur. Bunların hesaplanışı sırasıyla eşitlik (5), (6) ve (7)'de verilmiştir.

$$
\begin{gathered}
\text { Enerji }_{C_{l}}=\frac{1}{N_{l}} \sum_{i=1}^{N_{l}-1}\left|C_{l_{i}}\right|^{2} \\
\text { Skewness }_{C_{l}}=\left|\frac{\frac{1}{N_{l}} \sum_{i=0}^{N_{l}-1}\left(C_{l_{i}}-\mu_{l}\right)^{3}}{\sigma_{l}^{3}}\right| \\
\text { Kurtosis }_{C_{l}}=\frac{\frac{1}{N_{l}} \sum_{i=0}^{N_{l}-1}\left(C_{l_{i}}-\mu_{l}\right)^{4}}{\sigma_{l}^{4}}
\end{gathered}
$$

Eşitlik (5), (6) ve (7)'de $l$ değeri ADD seviyesini, $C_{l}$ ilgili seviyelerdeki katsayıları, $N_{l}$ ilgili seviyedeki katsayıların sayısını göstermektedir. Eşitlik (6) ve (7)'de $\mu_{l}$ değeri $C_{l}$ 'nin standart sapmasını göstermektedir.

Her seviyedeki katsayılardan öznitelikler hesaplanarak öznitelik vektörü oluşturulmuştur. Öznitelik vektörü her bir katsayıdan elde edilen 3 adet değer içermektedir. ADD seviyesine bağlı olarak toplam öznitelik sayısı belirlenmektedir.

\subsection{1. Özniteliklerin Analizi}

Şekil 4'te örnekleri verilen olay işaretlerinin her biri için 200 adet olmak üzere toplam 1200 adet olay işareti üretilmiştir. Olay işaretlerine düşük düzeyde gürültü eklenmiştir. Seçilen özniteliklerin olay türleri için ayırt edici nitelikte olup olmadığının incelenmesi amacıyla analiz yapılmıştır. Analiz için 5 farklı ADD seviyesinden ortanca olan 7 seviyesi tercih edilmiştir. ADD sonuncunda elde edilen detay ve yaklaşım katsayılarının ayrı ayrı enerji, basıklık ve kayıklık değerlerinin olay türüne göre aritmetik ortalamaları hesaplanmıştır.

Şekil 5, 6 ve 7'de ADD katsayılarının sırasıyla enerji, kayıklık ve basıklık özniteliklerinin aritmetik ortalamaları detay ve yaklaşım seviyelerine ve olay türüne göre gösterilmiştir. Hesaplanan özniteliklerin, farklı olay türleri için birbirine yakın değerlere sahip olduğu görülmektedir. Örneğin, Şekil 5'de verilen d2 ayrışım seviyesine ait enerji özniteliği grafiği incelendiğinde farklı olay sınıfları için ayırt edici olmadığı görülmektedir Bundan dolayı analizlerde tüm öznitelikler ve ayrışım seviyelerinin dikkate alınması anlamlı sonuçlar verecektir. Tüm öznitelikler ve ayrışım seviyeleri birlikte incelendiğinde, her bir olay türü için ayırt edici değer farklılıklarının olduğu görülmektedir. 
Ercire M., Ünsal A.: Kısa Süre. Güç Kalite. Bozulma. Dalgack. Analiz. Ve Rast. Orman Yönt. İle Sınıf.

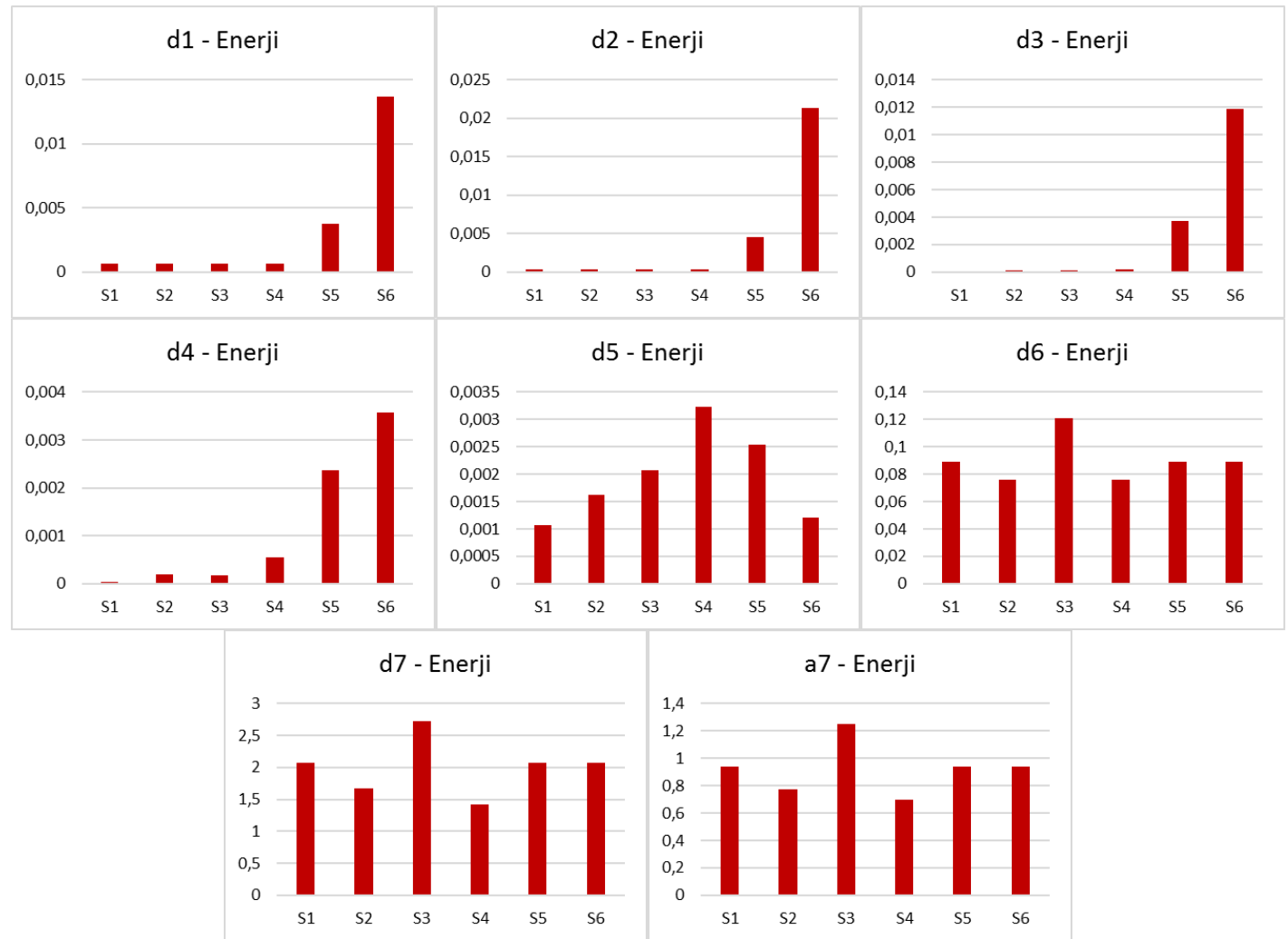

Şekil 5:

Olay türlerine ve ADD detay-yaklaşım seviyelerine göre katsayıların ortalama enerjileri.

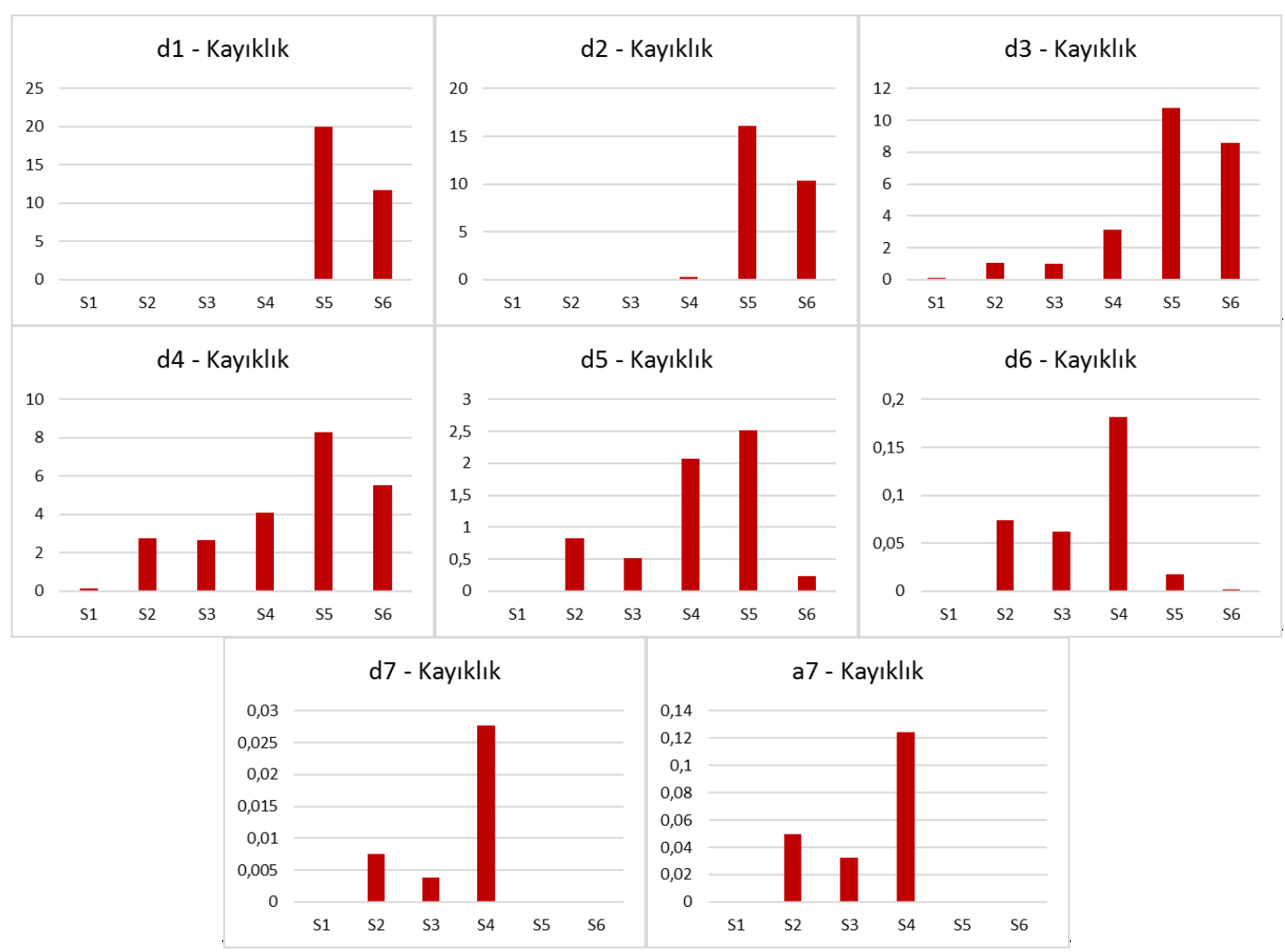

Şekil 6:

Olay türlerine ve ADD detay-yaklaşım seviyelerine göre katsayıların ortalama kayıklıları. 


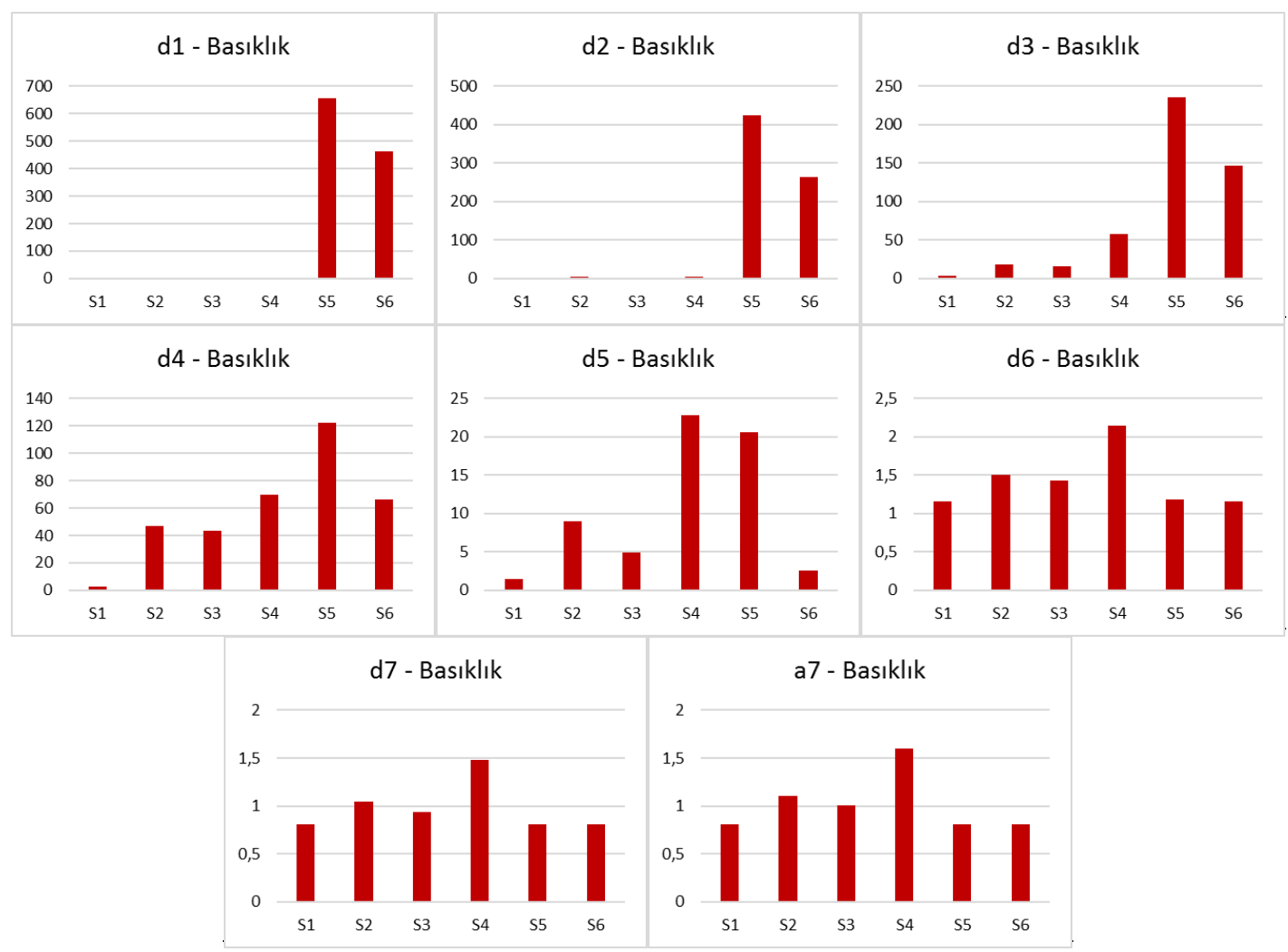

Şekil 7:

Olay türlerine ve ADD detay-yaklaşım seviyelerine göre katsayıların ortalama basıklıkları.

\subsection{Rastgele Orman Yöntemi ile Sınıflandırma}

$\mathrm{Bu}$ çalışmada topluluk karar ağacı yöntemlerinden RO yöntemi kullanılmıştır. RO sınıflandırıcısı için veri seti olarak olay işaretlerinden elde edilen öznitelik vektörleri kullanılmıştır. Sınıflandırma süreci veri madenciliği uygulamaları için geliştirilmiş WEKA Workbench yazılımı ile gerçekleştirilmiştir. WEKA (Waikato Environment for Knowledge Analysis) Yeni Zelanda'da bulunan Waikato Üniversitesi'nde geliştirilmiştir. WEKA makine öğrenmesi algoritmaları ve veri ön işleme araçlarını içermektedir. Girdi verilerinin hazırlanması, öğrenme şemalarının istatistiksel olarak değerlendirilmesi ve girdi verilerinin ve öğrenme sürecinin sonuçlarının görselleştirilmesi işlemleri yapılabilmektedir. Bu özellikleri ile veri madenciliği süreci için kapsamlı destek sağlamaktadır. (Eibe ve dĭğ., 2016)

Farklı düzeylerde gürültünün ve ADD seviyesinin sınıflandırıcı başarımına etkileri incelenerek Tablo 4'de verilmiştir. Tablo 4'de verilen sonuçlar incelendiğinde ADD seviyesi yükseldikçe başarım oranının arttığı görülmektedir. Özellikle gürültü düzeyi arttıkça daha yüksek seviyeli ADD ile daha iyi sonuçlar alınmaktadır. Bu durum ADD seviyesi yükseldikçe ayrıştırılan düşük frekanslı bant aralıklarının daralması ile ilişkilidir. Bu daralma daha düşük frekans bant aralıkları için daha fazla detay seviyesi katsayılarının elde edilmesini sağlamaktadır. Sonuç olarak ADD düşük frekanslar için daha detaylı bir dönüşüm sağlamakta ve düşük frekans bölgesine ilişkin daha fazla veri ortaya çıkmaktadır. Sonuçlar genel olarak değerlendirildiğinde 7 seviyeli ADD'nin öznitelik vektörü boyutu, performans ve sınıflandırma başarımı açısından yeterli ve uygun olduğu değerlendirilmiştir. 
Ercire M., Ünsal A.: Kısa Süre. Güç Kalite. Bozulma. Dalgack. Analiz. Ve Rast. Orman Yönt. İle Sınıf.

Tablo 4. Gürültü düzeyi ve ADD seviyesinin sınıflandırma başarımına etkisi.

\begin{tabular}{|l|c|c|c|c|}
\hline \multirow{2}{*}{ Gürültü Düzeyi } & \multicolumn{2}{|c|}{ En Yüksek Başarım } & \multicolumn{2}{c|}{ En Düşük Başarım } \\
\cline { 2 - 5 } & Oran & ADD Seviye & Oran & ADD Seviye \\
\hline Gürülttüsüz & $100,0 \%$ & 8 & $99,9 \%$ & $5,6,7,9$ \\
\hline Düşük & $99,8 \%$ & 7 & $99,3 \%$ & 6 \\
\hline Orta & $99,4 \%$ & 7 & $99,1 \%$ & 5 \\
\hline Yüksek & $98,5 \%$ & 9 & $97,8 \%$ & 5 \\
\hline
\end{tabular}

Güç sisteminde gerilim üzerindeki gürültü düzeyi değişkenlik göstermektedir. Bu nedenle gerçeğe daha uygun olarak farklı düzeylerde gürültülü olay işaretlerinin bulunması daha doğru bir yaklaşımdır. Bunun için her bir sınıfta temelde 200 adet olmak üzere ve 4 farklı düzeyde gürültü eklenmiş 800 adet olay işareti üretilmiştir. Tüm sınıflar için toplam olay işareti sayısı 4800 adettir. Bu olay işaretleri için 7 seviyeli ADD kullanılarak öznitelik çıkarımı yapılmıştır. Tablo 5'de bu olay işaretleri için sınıflandırma sonuçları verilmiştir. Sınıflandırma başarımı $\% 99,6$ olmuştur. Normal durum ile gerilim şişmesi hatasız sınıflandırılmıştır. Hatalı sınıflandırmalar incelendiğinde gerilim çökmesi ile gerilim kesintisi olaylarının karşılıklı olarak hatalı sınıflandırılabildiği görülmüştür. Benzer biçimde dürtüsel ve salınımlı süreksiz olayların da hatalı sınıflandırılabildiği görülmüştür.

Sinıflandırma sonuçları k-katlı çapraz doğrulama yöntemiyle $\mathrm{k}=20$ değeri için elde edilmiştir. Sınıflandırma doğruluğunu tutarlılık testinden geçirmek amacıyla olay işaretlerinin 3'te 2'si eğitim ve geri kalan 3'te 1'i test verisi olarak ayrılarak sınıflandırıcı test edilmiştir. Tablo 6'da verilen sonuçlar incelendiğinde k-katlı çapraz doğrulama başarımı ile eğitim ve test verisi olarak olay işaretlerini ayırmanın başarımı arasında \% 1,1 fark oluştuğu görülmüştür. Her iki yöntemle de ulaşılan başarım oranları birbirine yakın olmuştur. Elde edilen sonuçlara göre k-katlı çapraz doğrulama yöntemi ile elde edilen sonuçların tutarlı olduğu görülmüştür.

Tablo 5. Gürültülü olay işaretlerinin çapraz doğrulama ile RO sınıflandırma sonuçları

\begin{tabular}{|c|c|c|c|c|c|c|c|c|c|c|c|}
\hline & $\begin{array}{l}\bar{G} \\
\stackrel{\Xi}{0} \\
\bar{z}\end{array}$ & 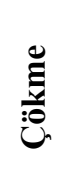 & 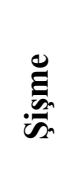 & 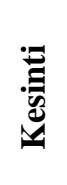 & 离 & 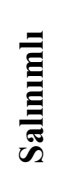 & 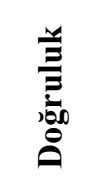 & 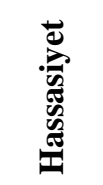 & 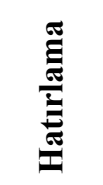 & 琶 & 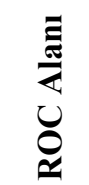 \\
\hline Normal & 800 & 0 & 0 & 0 & 0 & 0 & 1,000 & 0,998 & 1,000 & 0,999 & 1,000 \\
\hline Çökme & 0 & 793 & 0 & 7 & 0 & 0 & 0,991 & 0,999 & 0,991 & 0,995 & 1,000 \\
\hline Şişme & 0 & 0 & 800 & 0 & 0 & 0 & 1,000 & 1,000 & 1,000 & 1,000 & 1,000 \\
\hline Kesinti & 0 & 1 & 0 & 799 & 0 & 0 & 0,999 & 0,991 & 0,999 & 0,995 & 1,000 \\
\hline Dürtüsel & 2 & 0 & 0 & 0 & 793 & 5 & 0,991 & 0,997 & 0,991 & 0,994 & 1,000 \\
\hline Salınımlı & 0 & 0 & 0 & 0 & 2 & 798 & 0,998 & 0,994 & 0,998 & 0,996 & 1,000 \\
\hline \multicolumn{7}{|c|}{ Ağırlıkı Ortalama } & 0,996 & 0,996 & 0,996 & 0,996 & 1,000 \\
\hline
\end{tabular}


Tablo 6. Gürültülü olay işaretleri için $1 / 3$ test verisi ile RO sınıflandırma sonuçları

\begin{tabular}{|c|c|c|c|c|c|c|c|c|c|c|c|}
\hline & $\begin{array}{l}\overline{\tilde{g}} \\
\bar{\Xi} \\
\bar{z}\end{array}$ & $\frac{\mathscr{E}}{\stackrel{\Xi}{0}}$ & 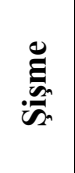 & 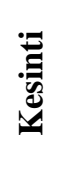 & 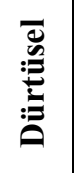 & 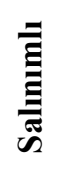 & 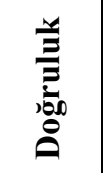 & 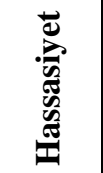 & 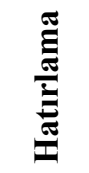 & 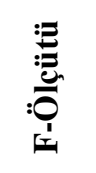 & 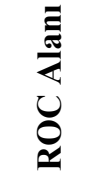 \\
\hline Normal & 267 & 0 & 0 & 0 & 0 & 1 & 0,996 & 1,000 & 0,996 & 0,998 & 1,000 \\
\hline Çökme & 0 & 254 & 0 & 11 & 0 & 0 & 0,958 & 0,996 & 0,958 & 0,977 & 1,000 \\
\hline Şişme & 0 & 0 & 282 & 0 & 0 & 0 & 1,000 & 1,000 & 1,000 & 1,000 & 1,000 \\
\hline Kesinti & 0 & 1 & 0 & 272 & 0 & 0 & 0,996 & 0,961 & 0,996 & 0,978 & 1,000 \\
\hline Dürt & 0 & 0 & 0 & 0 & 264 & 3 & 0,989 & 0,971 & 0,989 & 0,980 & 1,000 \\
\hline Salınımlı & 0 & 0 & 0 & 0 & 8 & 269 & 0,971 & 0,985 & 0,971 & 0,978 & 1,000 \\
\hline & & & Ag & & & ma & $\mathbf{0 , 9 8 5}$ & 0,986 & 0,985 & 0,985 & 1,000 \\
\hline
\end{tabular}

\section{SONUÇLAR}

$\mathrm{Bu}$ çalışmada şebeke geriliminde meydana gelen kısa süreli RMS değişimlerinin ve süreksiz olayların sınıflandırılması üzerinde çalışılmıştır. Bozulma olayı işaretleri matematiksel denklemlere dayalı olarak LabVIEW ile modellenmiştir.

Bozulma olayı işaretlerinin sınıflandırılması işaretlerden elde edilen öznitelikler kullanılarak gerçekleştirilmiştir. Özniteliklerin elde edilmesinde ADD yönteminden faydalanılmıştır. ADD yönteminde ayrıştırma seviyesinin başarıma etkisi incelenerek en yüksek başarımı sağlayacak seviye tespit edilmeye çalışılmıştır. ADD katsayılarından elde edilen enerji, kayıklık ve basıklık değerleri olay işaretinin özniteliklerini oluşturmaktadır. Öznitelik çıkarımı LabVIEW ile gerçekleştirilmiştir. Sınıflandırıcı olarak RO yöntemi kullanılmıştır. Sınıflandırıcı tasarımı WEKA WorkBench yazılımı ile gerçekleştirilmiştir.

ADD yönteminde 5 ile 9 arası tüm ayrıştırma seviyeleri için farklı gürültü düzeylerinde analiz yapılarak 7 seviyeli ADD'nin uygun olduğu görülmüştür. Şebeke işaretlerinin doğasına uygun olarak farklı düzeylerde gürültü içeren bozulmaların bir arada bulunduğu durumda RO sınıflandırıcısının başarımı test edilmiştir. Farklı düzeylerde gürültü içeren bozulmalarda başarım oranı k-katlı çapraz doğrulama ile \%99,6 olmuştur. Eğitim ve test verileri biçiminde bozulmaların ayrılması ile sınıflandırma başarım oranı \%98,5 olmuştur. Güç sistemi için olumsuz etkilere sahip olan gürültünün bozulmaların tespiti ve sınıflandırılmasını da olumsuz etkilediği görülmüştür. RO sınıflandırıcısı ile bozulmalar üzerinde oldukça başarılı sonuçlar elde edilmiştir. Çalışmada elde edilen en düşük başarım oranı \%97,8 doğrulukla yüksek gürültülü verilerde olmuştur. En düşük başarım oranı da dikkate alındığında ADD ve RO ile yapılan sınıflandırılmanın oldukça başarılı olduğu görülmüştür.

\section{ÇIKAR ÇATIŞMASI}

Yazarlar, bilinen herhangi bir çıkar çatışması veya herhangi bir kurum/kuruluş ya da kişi ile ortak çıkar bulunmadığını onaylamaktadırlar. 
Ercire M., Ünsal A.: Kısa Süre. Güç Kalite. Bozulma. Dalgack. Analiz. Ve Rast. Orman Yönt. İle Sınıf.

\section{YAZAR KATKISI}

Bu çalışma Mustafa ERCİRE’nin Kütahya Dumlupınar Üniversitesi Fen Bilimleri Enstitüsü Elektrik-Elektronik Mühendisliği Ana Bilim Dalında yaptığı yüksek lisans çalışmaları kapsamında hazırlanmıştır. Abdurrahman ÜNSAL çalışmanın kavramsal ve tasarım süreçlerinin belirlenmesi ve yönetimi, fikirsel içeriğin eleştirel incelemesi, Mustafa ERCIRE verilerin elde edilmesi, veri analizi ve yorumlama, makale taslağının oluşturulması, son onay ve tam sorumluluk kısımlarına katkı sağlamıştır.

\section{KAYNAKLAR}

1. Akman, M. (2010). Veri madenciliğine genel bakış ve random forests yönteminin incelenmesi: sağlık alanında bir uygulama, Yüksek Lisans Tezi, Ankara Üniversitesi Sağlık Bilimleri Enstitüsü, Ankara.

2. Borges, F.A., Fernandes, R.A., Lucas, A.M. ve Silva, I.N. (2015) Comparison between random forest algorithm and $\mathrm{J} 48$ decision trees applied to the classification of power quality disturbances, Proceedings of the International Conference on Data Mining (DMIN), Las Vegas, NV, 146-147.

3. Breiman, L. (2001) Random forests, Machine Learning, 45(1), 5-32. doi:10.1023/A:1010933404324

4. Brito, N.S.D., Souza, B.A. ve Pires, F.A.C. (1998) Daubechies wavelets in quality of electrical power, In 8th International Conference on Harmonics and Quality of Power. Proceedings (Cat. No. 98EX227), 1, 511-515. doi:10.1109/ICHQP.1998.759961

5. Chun-Lin, L. (2010) A tutorial of the wavelet transform, National Taiwan University Department of Electrical Engineering (NTUEE), Taiwan, 1-72.

6. Debnath, L. (2002) Wavelet Transforms \& Their Applications, Birkhäuser, Boston.

7. Eibe, F., Hall, M. A., ve Witten, I. H. (2016). The WEKA Workbench. Online Appendix for Data Mining: Practical Machine Learning Tools and Techniques. Morgan Kaufmann.

8. Getting Started with LabVIEW. Erişim Adresi: http://www.ni.com/pdf/manuals/373427f.pdf (Erişim Tarihi: 10.10 .2021 )

9. Goswami, J.C. ve Chan, A.K. (1999) Fundamentals of Wavelets, John Wiley\&Sons, USA

10. Huang, N., Lu, G., Cai, G., Xu, D., Xu, J., Li, F. ve Zhang, L. (2016) Feature selection of power quality disturbance signals with an entropy-importance-based random forest, Entropy, 18(2), 44-65. doi:10.3390/e18020044

11. Ibrahim, W.A. ve Morcos, M.M. (2002) Artificial intelligence and advanced mathematical tools for power quality applications: a survey. IEEE Transactions on Power Delivery, 17(2), 668-673. doi:10.1109/61.997958

12. IEEE Std 1159-2019. IEEE recommended practice for monitoring electric power quality. doi: IEEESTD.2019.8796486

13. Jamali, S., Farsa, A.R. ve Ghaffarzadeh, N. (2018) Identification of optimal features for fast and accurate classification of power quality disturbances, Measurement, 116, 565-574. doi:10.1016/j.measurement.2017.10.034

14. Kiranmai, S.A. ve Laxmi, A.J. (2018) Data mining for classification of power quality problems using WEKA and the effect of attributes on classification accuracy, Protection and Control of Modern Power Systems, 3(1), 1-12. doi:10.1186/s41601-018-0103-3 
15. Li, Y., Li, K., Liu, C., Xiao, X., Chen, X., ve Wang, M. (2021). Study on Denoising Algorithm for Power Quality Disturbances Based on Variational Mode Decomposition. Journal of Physics: Conference Series,1746(1). doi:1742-6596/1746/1/012061

16. Liaw, A. ve Wiener, M. (2002) Classification and regression by randomForest, $R$ News, 2(3), $18-22$.

17. Mahela, O.P., Shaik, A.G. ve Gupta, N. (2015) A critical review of detection and classification of power quality events, Renewable and Sustainable Energy Reviews, 41, 495505. doi:10.1016/j.rser.2014.08.070

18. Markovska, M. ve Taskovski, D. (2017a) On the choice of wavelet based features in power quality disturbances classification. In 2017 IEEE International Conference on Environment and Electrical Engineering and 2017 IEEE Industrial and Commercial Power Systems Europe (EEEIC/I\&CPS Europe), 1-6. doi:10.1109/EEEIC.2017.7977586

19. Markovska, M. ve Taskovski, D. (2017b) Optimal wavelet based feature extraction and classification of power quality disturbances using random forest, In IEEE EUROCON 201717th International Conference on Smart Technologies, 855-859. doi:10.1109/EUROCON.2017.8011232

20. Misiti, M., Misiti, Y., Oppenheim, G., ve Poggi, J. M. (2010). Wavelet Toolbox 4 User's Guide. The MathWorks.

21. Reddy, M.V. ve Sodhi, R. (2017) A modified S-transform and random forests-based power quality assessment framework, IEEE Transactions on Instrumentation and Measurement, 67(1), 78-89. doi:10.1109/TIM.2017.2761239

22. Sharma, A., Rajpurohit, B.S. ve Singh, S.N. (2018) A review on economics of power quality: Impact, assessment and mitigation, Renewable and Sustainable Energy Reviews, 88, 363-372. doi:10.1016/j.rser.2018.02.011

23. Tan, R.H. ve Ramachandaramurthy, V.K. (2010) Numerical model framework of power quality events, European Journal of Scientific Research, 43(1), 30-47.

24. Upadhyaya, S., Mohanty, S. ve Bhende, C.N. (2015) Hybrid methods for fast detection and characterization of power quality disturbances, Journal of Control, Automation and Electrical Systems, 26(5), 556-566. doi:10.1007/s40313-015-0204-4

25. Vatansever, F. (2020) Güç bileşenlerinin dalgacık dönüşümü tabanlı hesaplanması. Uludăg University Journal of The Faculty of Engineering, 25(2), 679-692. doi:10.17482/uumfd.717451 
